\title{
ДЕТЕРМІНАНТИ ДОМІНУЮЧИХ ПСИХІЧНИХ СТАНІВ УЧАСНИКІВ АТО
}

УДК: 159.942

\section{Євдокімова Олена Олександрівна}

\author{
Доктор психологічних наук, професор, завідувач \\ кафедри сочіології та психології Харківський націо- \\ нальний університет внутрішніх справ, м. Харків \\ (Україна) \\ ORCID ID: https://orcid.org/0000-0003-4211-7277
}

\begin{abstract}
Анотація. У запропонованій роботі досліджено вплив низки чинників на специффіку домінуючих психічних станів учасників АТО. Розглянуто складові домінуючих психічних станів комбатантів залежно від того: був чи не був досліджуваний під обстрілами, перебував чи не перебував у шпиталі, був чи не був свідком смерті під час бойових дій, добровільно чи за мобілізачією потрапив до зони бойових дій,чи були втрати близьких під час військової служби, залежно від терміну перебування в зоні бойових дій, залежно від сімейного стану (одруженийнеодружений), залежно від наявності дітей, залежно від працевлаштування тощчо. Емпіричне дослідження показало, щзо зі всіх досліджених чинників найбільший вплив на домінуючі психічні стани військовослужбовціів мають термін перебування у зоні бойових дій та занепокоєння, пов'язані з працевлаштуванням до служби.
\end{abstract}

Ключові слова: чинники, домінуючі психічні стани, комбатанти.

Постановка проблеми дослідження. вигляді виражених пограничних психічних У наслідок воєнних подій на сході України 3 розладів, адиктивної поведінки 3 формуванкожним днем збільшується частка громадян, які були учасниками АТО, ООС, брали участь в бойових діях, переживали втрати близьких людей, несли службу в екстремальних умовах, зазнавали значних психологічних потрясінь. Відповідно, актуалізуються питання мінімізації негативних психосоціальних наслідків у ням супутніх залежностей від алкоголю і наркотиків. Встановлено численні факти порушення адаптації учасників бойових дій в період повернення до мирного життя: підвищена конфліктність, високий рівень агресії, суїцидальна поведінка, алкоголізм, наркоманія тощо. Наслідки емоційної нестійкості комбатантів, 
що мають доступ до вогнепальної зброї, є потенційною загрозою заподіяння шкоди здоров'ю громадянам.

Психічний стан являє собою цілісну характеристику психічної діяльності людини за певний період часу, який показує своєрідність протікання психічних процесів в залежності від відображених предметів і явищ дійсності, від попереднього стану і властивостей особистості. На відміну від функціональних станів організму психічні стани людини відображають, $з$ певним ступенем адекватності, реальну життєву ситуацію і ставлення суб'єкта, а також залучають до процесу ії вирішення психічні процеси і особистісні властивості мотиваційну і емоційно-вольову сферу, характерологічні риси. Дослідження психічних станів людини для психологічної практики завжди було одним із провідних завдань, тому що психічні стани виступають одночасно і фоном, і найважливішим регулятором поведінки та діяльності суб'єкта. Домінуючі психічні стани визначають не тільки успішність будьякої професійної діяльності, але і якість життя в цілому. Тим важливішим, на нашу думку, виступає виявлення чинників, як психологічних, так і соціальних, які визначають домінуючі психічні стани людини.

Аналіз досліджень і публікацій. Людина завжди і всюди долала травми і своєрідно їх переживала. Перші відомі нам наукові відомості про це (так званий щоденник Samuel Pepys) сягають корінням в далекий 1666 рік
(R. J. Daly). Тоді після великої пожежі в Лондоні, було дано перший науковий опис психічної травми і показано зв'язок розладів із зовнішнім середовищем. Через 200 років (у 1863 році) Da Costa вперше описав психічні розлади в учасників громадянської війни в США внаслідок «незвичайного переживання» і назвав їх «синдромом подразненого серця». Дещо пізніше Е. Крепелін, а потім Е. Блейлер після першої світової війни описали психічні розлади, що виникають в результаті бойових дій, і виділили їх відповідно під назвами «травматичний невроз» $\mathrm{i}$ «невроз переляку».

Психологічні дослідження, що присвячені ролі емоційного компоненту самосвідомості в переживанні психотравмуючих ситуацій, його зв'язку з особливостями цих переживань, можна охарактеризувати такими напрямами:

дослідження, в яких зазначається вплив емоційного компоненту самосвідомості на переживання ПТС, роль самооцінки, самоповаги та самоприйняття у цьому процесі (Р. Бернс, М. Розенберг, I. Чеснокова, I.М. Трубавіна, Г. Каплан, С. Кобаза);

дослідження, в яких наголошується на зміні проявів емоційного компоненту самосвідомості при переживанні ПТС як механізмів, що забезпечують психологічний захист особистості з метою збереження цілісності «образу Я» і вироблення стратегії адаптації особистості. Це може зумовлювати як конструктивні особистісні зміни (Т. Кириленко, 
T. Титаренко, В. Бодров, В. Лушин, I. Маноха), так і деструктивні, що призводять до деградації особистості (Н. Максимова та iн).

У дизайні нашого вивчення, цікавим $є$ дослідження С. Р. Аксельрода [3, с.270], у якому автор зосереджує увагу на еволюції симптомів, пов'язаних з травмою, у ветеранів операції «Буря в пустелі» в Перській затоці. На матеріалі вивчення дев'яноста чотирьох резервістів С. Р. Аксельрод досліджує зв'язок між тяжкістю пов'язаних 3 війною травм, симптомів посттравматичного стресового розладу (ПТСР) та симптомів пограничного розладу особистості із змішаним ретроспективним / перспективним дизайном. Автор приходить висновку, що вплив довоєнних особливостей пограничного розладу особистості на післявоєнні симптоми ПТСР перевищує вплив власне участі у бойових діях. Автор зазначає, що травма, симптоми ПТСР та особливості пограничного розладу особистості пов'язані між собою складно, що може перевершувати прості лінійні моделі [3, с.270].

Вплив довоєнних і післявоєнних чинників на емоційний стан учасників бойових дій вивчала у своїй роботі також Крис Брюїн зі співавторами [4, с. 748]. Дослідниця визначила три категорії факторів ризику: такі фактори, як стать, вік травми і раса; такі чинники, як освіта, попередня травма і загальна недоглянутість дітей, які обумовлювали ПТСР більш послідовно, але в різному ступені в за- лежності від досліджуваного населення і використовуваних методів; i такі чинники, як психіатрична історія, повідомлення про жорстоке поводження $з$ дітьми та сімейна психіатрична історія, які мали більш рівномірні прогностичні ефекти [4, с. 748].

Стівен Джозеф намагається виявити позитивні наслідки травматичних подій [6, с. 335]. Автор розглядує ідею про те, що в стражданні є особиста користь. Він пише, що спостереження щодо того, що стресові та травматичні події можуть спровокувати позитивні психологічні зміни, також містяться в основних релігіях буддизму, християнства, індуїзму, ісламу та іудаїзму. В рамках екзистенціальної філософії та гуманістичної психології також було визнано, що в результаті страждань можуть виникнути позитивні зміни [6, c. 335]. Х. Приджерсон, навпаки, пише про бойову травму як про травму 3 найбільшим ризиком відстроченого початку, про нерозв'язані симптоми посттравматичного стресу, безробіття й інші лиха й поневіряння учасників бойових дій [9, с. 99]. Ричард Кулька аналізує перспективи і підводні камені недавніх досліджень ветеранів В'єтнаму [7, с. 547].

За Л. В. Куликовим, «у психічних станах інтегрована актуальна вираженість рис особистості, сила їх прояву. Хоча стани роблять значущий вплив на формування рис, зворотний вплив (з боку рис) і для поточних, i для стійких станів є значно сильнішим. Дослідник зауважує, що «у станах завжди є і ситуа- 
тивна, і трансситуативна складова. При цьому тут некоректно говорити про будь-який статистичний баланс. Певні події або умови поточної ситуації можуть надовго «потіснити» трансситуативну складову i значною мірою визначити багато параметрів станів, обмежуючи їх можливу різноманітність» [2, с.11-12].

О. Б. Ігумнова психічний стан розглядає як складне, інтегративне, цілісне, поліфункціональне та поліструктурне явище психічного життя особистості. Виникнення психічних станів первинно зумовлено особливостями взаємодії суб'єкта з різними ситуаціями життєдіяльності, у яких уреальнюються його психічні властивості, особистісні смисли, досвід, система ставлень до дійсності та самого себе. Детермінантами виникнення психічних станів є різноманітні ситуації, сам суб'єкт та особистісний смисл як їх системоутворювальний чинник. Особистісні смисли як утворення, що набуваються та закріплюються під впливом особистісних переживань індивіда, самі стають джерелом таких переживань. Особистісні смисли виникають та закріплюються у досвіді індивіда й визначають суттєві характеристики особистості, складають її свідомість. Суб’єктивне відношення людини до світу складає основу особистісних смислів індивіда, які не піддаються безпосередньому довільному контролю, і визначають особливості виникнення й перебігу в подальшому психічних станів індивіда [1, с. $64-65]$.

Домінуючий стан - це стан, що перева- жає в часі, поглинаючи велику його частину. Такі стани є характерними не стільки в даний конкретний момент, що залежить від особливостей певної ситуації, скільки взагалі для певного періоду життя людини. Вони меншою мірою обумовлені актуальною, поточною ситуацією, яка має точно окреслені часові рамки, i більшою мірою - соціальнопсихологічними особистісними факторами. Зрозуміло, що при такому ракурсі розгляду в структурі психічного стану необхідно виділяти не тільки «домінуючу», але i «ситуативну» («поточну») складову. На тлі домінуючих станів формуються і існують актуальні стани [2, с. 17]. Домінуючі стани можуть визначатися багатьма впливами. Ми поставили собі за мету виявити специфіку домінуючих психічних станів учасників АТО залежно від таких, на перший погляд, очевидних, але, як з'ясувалося мало досліджених, чинників як «був чи не був досліджуваний під обстрілами», «перебував / не перебував у шпиталі», «був / не був свідком смерті», «доброволець / мобілізований», «втрата близьких під час військової служби», від терміну перебування в зоні бойових дій, від сімейного стану (одружений-неодружений), від наявності дітей, від наявності працевлаштування до воєнних подій тощо.

Мета статті - дослідження чинників, що визначають специфіку домінуючих психічних станів комбатантів АТО. Відповідно, ми вирішували завдання 3 виявлення специфіки 
домінуючих психічних станів учасників АТО залежно від того:

- $\quad$ був чи не був досліджуваний під обстрілами,

- $\quad$ перебував чи не перебував у шпиталі,

- був чи не був свідком смерті під час бойових дій,

- $\quad$ добровільно чи за мобілізацією потрапив до зони бойових дій,

- чи були втрати близьких під час військової служби,

- $\quad$ залежно від терміну перебування в зоні бойових дій,

- $\quad$ залежно від сімейного стану (одружений -неодружений),

- залежно від наявності дітей,

- $\quad$ залежно від працевлаштування тощо.

У якості досліджуваних виступили 120 демобілізованих військових одного з батальйонів, які проходили службу у зоні АТО.

Методи дослідження. 3 метою 3'ясування частоти представленості чинників прояву посттравматичних стресових станів комбатантів АТО нами була створена анкета, яка дозволила встановити вікові відмінності, соціальні рівні, стресогенність, тривалість і масштабність участі у військових діях, а також їх сімейний статус. В анкеті використовувались 20 запитань відкритої форми

Для визначення особливостей домінуючих психічних станів використовували методику «Виявлення домінуючих станів» Л. В. Куликова. Призначення методики - визна- чення характеристик настроїв $\mathrm{i}$ деяких інших характеристик особистісного рівня психічних станів за допомогою суб'єктивних оцінок досліджуваного. Першочерговим призначенням опитувальника $\epsilon$ діагностика стійких (домінуючих) станів. Основними шкалами є:

Шкала «Ак»: «активне - пасивне відношення до життєвої ситуації»

Шкала «Сп»: «спокій - тривога»

Шкала «Ус»: «стійкість - нестійкість емоційного тону»

Шкала «Уд»: «задоволеність - незадоволеність життям в цілому (його ходом, процесом самореалізаціі)»

Контрольна шкала «По»: «позитивне негативне уявлення про самого себе» $[2$, c. 38].

У якості метода математичної статистики було використано t-критерій Стьюдента для незалежних вибірок, який визначався за допомогою комп'ютерної програми SPSS 17 for Windows.

Виклад основного матеріалу дослідження. Вивчення особливостей домінуючих психічних станів у комбатантів АТО було проведено нами за низкою критеріїв. Показники домінуючих психічних станів комбатантів у групах, сформованих за критерієм « Був чи не був досліджуваний під обстрілами», надано в Таблиці 1.

Математико-статистичний аналіз не виявив відмінностей у показниках домінуючих психічних станів між групами, представ- 
Показники домінуючих психічних станів комбатантів за критерісм «Був/не був під обстрілами»( $М \pm$ б)

\begin{tabular}{|l|l|l|l|l|}
\hline Показники & $\begin{array}{l}\text { I група N=88 } \\
\text { «був під обстрілами» }\end{array}$ & $\begin{array}{l}\text { IІ група N=32 } \\
\text { «не був під обстріла- } \\
\text { ми» }\end{array}$ & T & P \\
\hline $\begin{array}{l}\text { Активне-пасивне став- } \\
\text { лення до життя }\end{array}$ & $39,27 \pm 16,37$ & $46,37 \pm 16,77$ & 1,47 & 0,15 \\
\hline Тонус: високий-низький & $53,04 \pm 7,07$ & $56,37 \pm 7,00$ & 1,61 & 0,11 \\
\hline Спокій - тривога & $50,36 \pm 16,27$ & $52,00 \pm 5,93$ & 0,39 & 0,69 \\
\hline $\begin{array}{l}\text { Стійкість - нестійкість } \\
\text { емоційного стану }\end{array}$ & $50,18 \pm 14,33$ & $55,00 \pm 8,29$ & 1,26 & 0,21 \\
\hline $\begin{array}{l}\text { Задоволеність - незадо- } \\
\text { воленість життям в ціло- } \\
\text { му }\end{array}$ & $58,14 \pm 9,58$ & $54,13 \pm 8,95$ & 1,46 & 0,15 \\
\hline $\begin{array}{l}\text { Позитивне-негативне уя- } \\
\text { влення про самого себе }\end{array}$ & $53,50 \pm 7,62$ & $54,00 \pm 7,21$ & 0,22 & 0,82 \\
\hline
\end{tabular}

ники яких перебували чи не перебували під обстрілами.

Показники домінуючих психічних станів комбатантів у групах, сформованих за критерієм «Був чи не був досліджуваний у шпита- нів комбатантів у групі, представники якої перебували у шпиталі, та групи, представники якої у шпиталі не перебували, відповідно склали: за шкалою «Активне-пасивне ставлення до життя» - 41,82 $\pm 16,98$ та $40,30 \pm 16,46$;

Таблиия 2.

Показники домінуючих психічних станів комбатантів за критерієм «Перебував / не перебував у шпталі»( $\mathrm{M} \pm$ б)

\begin{tabular}{|l|l|l|l|l|}
\hline Показники & $\begin{array}{l}\text { I група N=68 } \\
\text { «Був у шпиталі» }\end{array}$ & $\begin{array}{l}\text { I група N=52 } \\
\text { «Не був у шпита- } \\
\text { лі» }\end{array}$ & T & P \\
\hline $\begin{array}{l}\text { Активне-пасивне ставлення до } \\
\text { життя }\end{array}$ & $41,82 \pm 16,98$ & $40,30 \pm 16,46$ & 0,34 & 0,72 \\
\hline Тонус: високий-низький & $54,70 \pm 6,21$ & $52,92 \pm 8,24$ & 0,95 & 0,34 \\
\hline Спокій - тривога & $51,41 \pm 13,07$ & $50,00 \pm 15,87$ & 0,37 & 0,70 \\
\hline $\begin{array}{l}\text { Стійкість - не стійкість емо- } \\
\text { ційного стану }\end{array}$ & $51,94 \pm 9,63$ & $50,64 \pm 16,79$ & 0,31 & 0,75 \\
\hline $\begin{array}{l}\text { Задоволеність - незадоволе- } \\
\text { ність життям в цілому }\end{array}$ & $56,35 \pm 9,28$ & $58,00 \pm 9,91$ & 0,67 & 0,51 \\
\hline $\begin{array}{l}\text { Позитивне-негативне уявлен- } \\
\text { ня про самого себе }\end{array}$ & $54,47 \pm 7,62$ & $52,53 \pm 7,21$ & 0,99 & 0,32 \\
\hline
\end{tabular}

лі», надано в Таблиці 2.

Показники домінуючих психічних ста-
«Тонус: високий-низький» - 54,70 $\pm 6,21$ та $52,92 \pm 8,24$; «Спокій - тривога» - 51,41 $\pm 13,07$ 


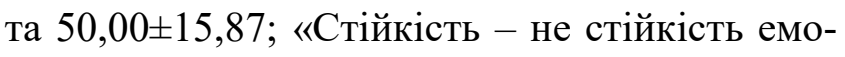
ційного стану» - 51,94 $\pm 9,63$ та 50,64 $\pm 16,79$; «Задоволеність - незадоволеність життям в цілому» - 56,35 $\pm 9,28$ та $58,00 \pm 9,91$; «Позитивний-негативний уявлення про само-

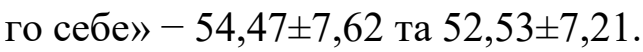

За всіма вищезазначеними шкалами математико-статистичний аналіз не виявив відмінностей у показниках домінуючих психічних станів між групами, сформованими за критерієм перебування на лікуванні у шпиталі.

Показники домінуючих психічних ста-

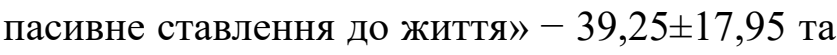
$45,00 \pm 13,21$; «Тонус: високий-низький» $51,85 \pm 7,25$ та $56,10 \pm 6,57$; «Спокій - триво-

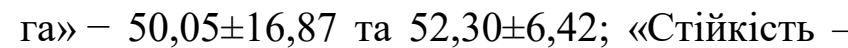

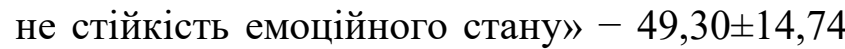

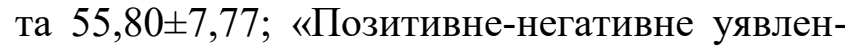

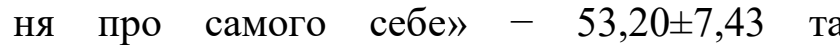
$54,50 \pm 7,59$.

Показники домінуючих психічних станів в групі комбатантів, які були свідками смерті, та у групі військовослужбовців, які не спостерігали смерть, відповідно склали: за шкалою «Активне-пасивне ставлення до жит-

Таблиця 3.

\section{Показники домінуючих психічних станів комбатантів за критерісм «Був/не був свідком смерті»( $\mathrm{M} \pm$ ठ)}

\begin{tabular}{|l|l|l|l|l|}
\hline Показники & $\begin{array}{l}\text { І група N=60 } \\
\text { «Був свідком смерті» }\end{array}$ & $\begin{array}{l}\text { II група N=60 } \\
\text { «Не був свідком смер- } \\
\text { ті»» }\end{array}$ & T & P \\
\hline $\begin{array}{l}\text { Активне-пасивне ставлення } \\
\text { до життя }\end{array}$ & $39,25 \pm 17,95$ & $45,00 \pm 13,21$ & 1,27 & 0,20 \\
\hline Тонус: високий-низький & $51,85 \pm 7,25$ & $56,10 \pm 6,57$ & 1,68 & 0,97 \\
\hline Спокій - тривога & $50,05 \pm 16,87$ & $52,30 \pm 6,42$ & 0,57 & 0,57 \\
\hline $\begin{array}{l}\text { Стійкість - не стійкість емо- } \\
\text { ційного стану }\end{array}$ & $49,30 \pm 14,74$ & $55,80 \pm 7,77$ & 1,84 & 0,07 \\
\hline $\begin{array}{l}\text { Задоволеність - незадоволе- } \\
\text { ність життям в цілому }\end{array}$ & $59,10 \pm 9,11$ & $53,00 \pm 9,19$ & 2,43 & $\mathbf{0 , 0 1}$ \\
\hline $\begin{array}{l}\text { Позитивне-негативне уявлен- } \\
\text { ня про самого себе }\end{array}$ & $53,20 \pm 7,43$ & $54,50 \pm 7,59$ & 0,63 & 0,52 \\
\hline
\end{tabular}

нів комбатантів у групах, сформованих за критерієм «Був чи не був досліджуваний свідком смерті», надано в таблиці 3. Показники домінуючих психічних станів в групі комбатантів, які були свідками смерті, та у групі військовослужбовців, які не спостерігали смерть, відповідно склали: за шкалою «Активне-

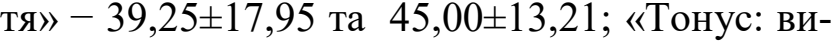

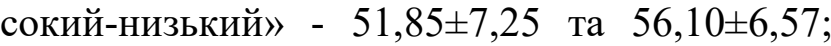
«Спокій - тривога» - 50,05 16,87 та $52,30 \pm 6,42$; «Стійкість - не стійкість емоцій-

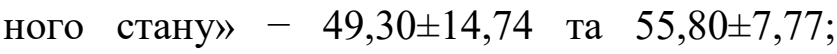
«Позитивне-негативне уявлення про самого себе» $-53,20 \pm 7,43$ та $54,50 \pm 7,59$. 
За вищезазначеними шкалами математико-статистичний аналіз не виявив відмінностей у показниках домінуючих психічних станів між групами, сформованими за критерієм «Був/не був свідком смерті».

За шкалою «Задоволеність - незадоволеність життям в цілому» у групі комбатантів, котрі спостерігали смерть, показник був віро-

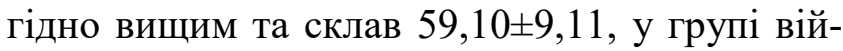
ськовослужбовців, які не були свідками смерті, показник за цією шкалою дорівнював $53,00 \pm 9,19(\mathrm{t}=2,43, \mathrm{p} \leq 0,01)$. Отже, комбатанти, які були свідками смерті, більш цінують життя в цілому, більше задоволені його ходом та самореалізацією. Вони відчувають більшу готовність долати труднощі в реалізації власних здібностей, більшу здатність брати на себе відповідальність та бачать більше можливостей зробити власний вибір. строком перебування у зоні воєнних дій надано в Таблиці 4.

Показники домінуючих психічних станів в групі комбатантів, які перебували у зоні бойових дій різний період часу, відповідно склали: за шкалою «Тонус: високийнизький» $-54,53 \pm 8,11$ та $36,13 \pm 14,61$; за шка-

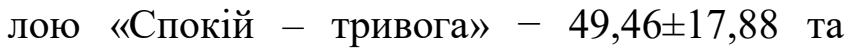
$52,13 \pm 9,41$; за шкалою «Стійкість - не стій-

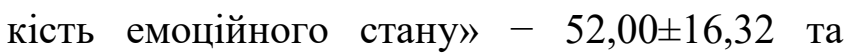
$50,93 \pm 9,07$; за шкалою «Задоволеність - незадоволеність життям в цілому» - 56,071 $\pm 0,99$ та $58,07 \pm 7,83$.

За шкалою «Активне-пасивне ставлення до життя» в групі комбатантів, що перебували у зоні бойових дій до 60 днів, показник

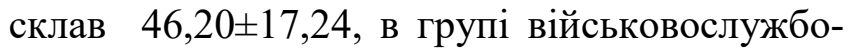
ців, які перебували в зоні бойових дій до 150 днів, показник за цією шкалою $є$ вірогідно

Таблиия 4.

\section{Показники домінуючих психічних станів комбатантів за строком перебування у зоні воснних дій ( $\mathrm{M} \pm$ ठ)}

\begin{tabular}{|l|l|l|l|l|}
\hline Показники & $\begin{array}{l}\text { I група N=60 } \\
\text { До 60 днів }\end{array}$ & $\begin{array}{l}\text { I група N=60 } \\
\text { До 150 днів }\end{array}$ & T & $\mathbf{P}$ \\
\hline $\begin{array}{l}\text { Активне-пасивне ставлення до } \\
\text { життя }\end{array}$ & $46,20 \pm 17,24$ & $36,13 \pm 14,61$ & 2,44 & $\mathbf{0 , 0 2}$ \\
\hline Тонус: високий-низький & $54,53 \pm 8,11$ & $53,33 \pm 6,12$ & 0,65 & 0,52 \\
\hline Спокій - тривога & $49,46 \pm 17,88$ & $52,13 \pm 9,41$ & 0,72 & 0,47 \\
\hline $\begin{array}{l}\text { Стійкість - не стійкість емоційного } \\
\text { стану }\end{array}$ & $52,00 \pm 16,32$ & $50,93 \pm 9,07$ & 0,31 & 0,75 \\
\hline $\begin{array}{l}\text { Задоволеність - незадоволеність } \\
\text { життям в цілому }\end{array}$ & $56,071 \pm 0,99$ & $58,07 \pm 7,83$ & 0,81 & 0,42 \\
\hline $\begin{array}{l}\text { Позитивне-негативне уявлення } \\
\text { про самого себе }\end{array}$ & $55,60 \pm 8,36$ & $51,67 \pm 5,92$ & 2,10 & $\mathbf{0 , 0 4}$ \\
\hline
\end{tabular}

Показники домінуючих психічних станів комбатантів у групах, сформованих за більш низьким та дорівнюе $36,13 \pm 14,61$ ( $\mathrm{t}=$ $2,44, \mathrm{p} \leq 0,02)$, що відбиває більш пасивне ста- 
влення представників цієї групи до життєвої ситуації та їх недостатню віру в можливість успішного подолання перешкод. Дослідження показало, що зі збільшенням часу перебування в ATO, настрій та оптимізм дещо знижуються.

Визначено також вірогідно більш високі показники за шкалою «Позитивненегативне уявлення про самого себе» в групі комбатантів, що перебували у зоні бойових дій до 60 днів $(55,60 \pm 8,36)$, на відміну від військовослужбовців, які перебували в зоні бойових дій більше двох місяців $(51,67 \pm 5,92)$, при $\mathrm{t}=2,10, \mathrm{p} \leq 0,04$. Отже, комбатанти, що перебували у зоні бойових дій до 60 днів, меш критично оцінюють себе та більш схильні приймати себе з усіма своїми недоліками.

Показники домінуючих психічних станів комбатантів у групах, сформованих за критерієм мотивації участі у бойових діях, надано в Таблиці 5.

Між групою добровольців та комбатан- тів, які були мобілізовані, не було встановлено вірогідних відмінностей за наступними шкалами, показники за якими склали відповідно: «Активне-пасивне ставлення до життя» $39,88 \pm 13,84$ та 42,84 $\pm 19,87$; «Тонус: високийнизький» - 54,58 16,70 та $53,07 \pm 7,85$; «Стійкість - не стійкість емоційного стану» $53,17 \pm 8,57$ та 49,23 $\pm 17,29$; «Задоволеність незадоволеність життям в цілому» $50,41 \pm 9,38$ та $57,92 \pm 9,80$; «Позитивненегативне уявлення про самого себе» $53,64 \pm 6,81$ та 53,61 $\pm 8,35$.

За шкалою «Спокій - тривога», в порівнянні із групою мобілізованих $(45,15 \pm 18,80)$, у групі добровольців встановлено вірогідно більш високий показник $(55,12 \pm 7,07)$, при $\mathrm{t}=$ 2,84, $\mathrm{p} \leq$ 0,006, що свідчить про їх більшу впевненість в своїх силах та можливостях.

Показники домінуючих психічних станів комбатантів у групах, сформованих за політичним критерієм участі у бойових діях, на-

Таблиия 5.

Показники домінуючих психічних станів комбатантів за мотиваційним критерієм «Доброволець/мобілізований»( $\mathrm{M} \pm$ б)

\begin{tabular}{|l|l|l|l|l|}
\hline Показники & $\begin{array}{l}\text { I група N=68 } \\
\text { доброволець }\end{array}$ & $\begin{array}{l}\text { II група N=52 } \\
\text { мобілізова- } \\
\text { ний }\end{array}$ & T & P \\
\hline $\begin{array}{l}\text { Активне-пасивне ставлення до жит- } \\
\text { тя }\end{array}$ & $39,88 \pm 13,84$ & $42,84 \pm 19,87$ & 0,68 & 0,49 \\
\hline Тонус: високий-низький & $54,58 \pm 6,70$ & $53,07 \pm 7,85$ & 0,80 & 0,42 \\
\hline Спокій - тривога & $55,12 \pm 7,07$ & $45,15 \pm 18,80$ & 2,84 & $\mathbf{0 , 0 0 6}$ \\
\hline $\begin{array}{l}\text { Стійкість - не стійкість емоційного } \\
\text { стану }\end{array}$ & $53,17 \pm 8,57$ & $49,23 \pm 17,29$ & 1,15 & 0,25 \\
\hline $\begin{array}{l}\text { Задоволеність - незадоволеність } \\
\text { життям в цілому }\end{array}$ & $50,41 \pm 9,38$ & $57,92 \pm 9,80$ & 0,60 & 0,54 \\
\hline $\begin{array}{l}\text { Позитивне-негативне уявлення про } \\
\text { самого себе }\end{array}$ & $53,64 \pm 6,81$ & $53,61 \pm 8,35$ & 0,01 & 0,98 \\
\hline
\end{tabular}

(C) Свдокімова O.O. 
Показники домінуючих психічних станів комбатантів за політичним критерієм (

\begin{tabular}{|l|l|l|l|l|}
\hline Показники & $\begin{array}{l}\text { I група N=60 } \\
\text { «Брав участь у Pe- } \\
\text { волюції гідності» }\end{array}$ & $\begin{array}{l}\text { II група N=60 } \\
\text { «не брав учас- } \\
\text { ті у Революції } \\
\text { гідності» }\end{array}$ & $\mathbf{T}$ & $\mathbf{P}$ \\
\hline $\begin{array}{l}\text { Активне-пасивне ставлення до } \\
\text { життя }\end{array}$ & $44,80 \pm 20,87$ & $37,53 \pm 9,99$ & 1,72 & 0,09 \\
\hline Тонус: високий-низький & $55,86 \pm 6,20$ & $52,00 \pm 7,60$ & 2,15 & $\mathbf{0 , 0 4}$ \\
\hline Спокій - тривога & $51,13 \pm 10,83$ & $50,47 \pm 17,16$ & 0,18 & 0,85 \\
\hline $\begin{array}{l}\text { Стійкість - не стійкість емо- } \\
\text { ційного стану }\end{array}$ & $53,26 \pm 9,03$ & $49,67 \pm 16,16$ & 1,06 & 0,29 \\
\hline $\begin{array}{l}\text { Задоволеність - незадоволе- } \\
\text { ність життям в цілому }\end{array}$ & $53,73 \pm 9,58$ & $60,40 \pm 8,32$ & 2,87 & $\mathbf{0 , 0 0 5}$ \\
\hline $\begin{array}{l}\text { Позитивний-негативний уяв- } \\
\text { лення про самого себе }\end{array}$ & $52,60 \pm 5,50$ & $54,67 \pm 8,97$ & 1,07 & 0,28 \\
\hline
\end{tabular}

дано в Таблиці 6.

Показники домінуючих психічних станів у групі, представники якої брали участь у Революції гідності, та групи, представники якої не виявляли такої політичної активності, відповідно склали: за шкалою «Активнепасивне ставлення до життя» $-44,80 \pm 20,87$ та $37,53 \pm 9,99$; за шкалою «Спокій - тривога» $51,13 \pm 10,83$ та $50,47 \pm 17,16$; за шкалою «Стійкість - не стійкість емоційного стану» $53,26 \pm 9,03$ та $49,67 \pm 16,16 ;$ за шкалою «Позитивне-негативне уявлення про самого себе» $-52,60 \pm 5,50$ та $54,67 \pm 8,97$.

За шкалою «Тонус: високий-низький» у комбатантів, які брали участь у Революції гід-

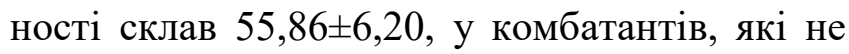
брали участь у Революції гідності він стано-

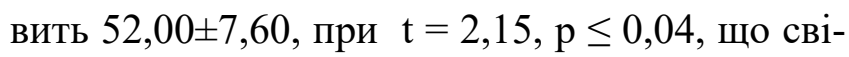

дчить про більш високу стійкість збудження нервової системи, яке не супроводжується втомою.

Отже, комбатантів, що брали участь у Революції гідності, характеризує більш висока активність, більш виражене суб'єктивне відчуття внутрішньої зібраності, запасу сил та енергіï.

За шкалою «Задоволеність - незадоволеність життям в цілому» у комбатантів, які брали участь у Революції гідності склав $53,73 \pm 9,58$, у комбатантів, які не брали участь у Революції гідності він становить 60,40土8,32, при $\mathrm{t}=2,87, \mathrm{p} \leq 0,005$. Тобто, комбатантам, котрі не брали участі у Революції гідності, більш притаманними є задоволеність життям в цілому, його ходом та самореалізацією; готовність долати труднощі в реалізації власних 
здібностей, здатність брати на себе відповідальність та вбачати більше можливостей зробити власний вибір.

Показники домінуючих психічних станів комбатантів у групах, сформованих за критерієм «Втрата близьких під час військової себе» $-53,53 \pm 6,62$ та 53,73 $\pm 8,32$.

За всіма вищезазначеними шкалами математико-статистичний аналіз не виявив відмінностей у показниках домінуючих психічних станів між групами, сформованими за критерієм «Втрата близьких під час військової

Таблиия 7.

\section{Показники домінуючих психічних станів комбатантів за критерісм «Втрата близьких під час військової служби» ( $\mathrm{M} \pm$ ð)}

\begin{tabular}{|l|l|l|l|l|}
\hline Показники & $\begin{array}{l}\text { І група N=60 } \\
\text { Була втрата бли- } \\
\text { зьких }\end{array}$ & $\begin{array}{l}\text { ІІ група N=60 } \\
\text { Не було втрати бли- } \\
\text { зьких }\end{array}$ & T & P \\
\hline $\begin{array}{l}\text { Активне-пасивне ставлення } \\
\text { до життя }\end{array}$ & $41,27 \pm 16,48$ & $41,07 \pm 17,06$ & 0,05 & 0,96 \\
\hline Тонус: високий-низький & $53,53 \pm 5,45$ & $54,33 \pm 8,59$ & 0,43 & 0,67 \\
\hline Спокій - тривога & $51,73 \pm 11,74$ & $49,87 \pm 16,51$ & 0,50 & 0,62 \\
\hline $\begin{array}{l}\text { Стійкість - не стійкість емо- } \\
\text { ційного стану }\end{array}$ & $52,60 \pm 8,54$ & $50,33 \pm 16,54$ & 0,66 & 0,51 \\
\hline $\begin{array}{l}\text { Задоволеність - незадоволе- } \\
\text { ність життям в цілому }\end{array}$ & $56,46 \pm 9,53$ & $57,67 \pm 9,62$ & 0,48 & 0,63 \\
\hline $\begin{array}{l}\text { Позитивне-негативне уяв- } \\
\text { лення про себе }\end{array}$ & $53,53 \pm 6,62$ & $53,73 \pm 8,32$ & 0,10 & 0,91 \\
\hline
\end{tabular}

служби», надано в Таблиці 7.

Показники домінуючих психічних станів комбатантів у групі, представники якої втратили близьких під час військової служби, та групи, представники якої не зазнали таких втрат, відповідно склали: за шкалою «Активне

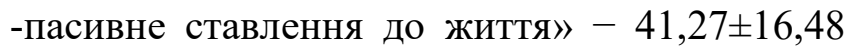

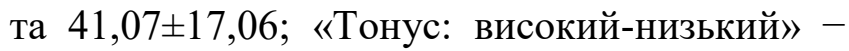

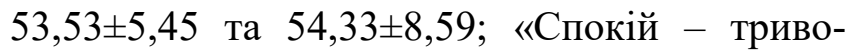

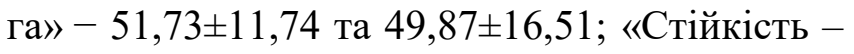
не стійкість емоційного стану» $-52,60 \pm 8,54$ та $50,33 \pm 16,54$; «Задоволеність - незадоволеність життям в цілому» $-56,46 \pm 9,53$ та $57,67 \pm 9,62$; «Позитивне-негативне уявлення про самого служби». Дослідження показало, що комбатанти, котрі втратили близьких під час війни, $є$ більш схильними відчувати занепокоєння у широкому колі життєвих ситуацій, чекати подій 3 негативними наслідками, передчувати загрозу незалежно від того, наскільки реальними є причини.

Показники домінуючих психічних станів комбатантів у групах, сформованих за сімейним станом, надано в Таблиці 8.

Визначено наступні показники домінуючих психічних станів в групах одружених та неодружених комбатантів: за шкалою «Активне-пасивне ставлення до життя» - 


\section{Показники домінуючих психічних станів одружених та неодружених комбатантів (M \pm б)}

\begin{tabular}{|l|l|l|l|l|}
\hline Показники & $\begin{array}{l}\text { I група N=60 } \\
\text { «Одружені» }\end{array}$ & $\begin{array}{l}\text { II група N=60 } \\
\text { «Неодружені» }\end{array}$ & T & P \\
\hline $\begin{array}{l}\text { Активне-пасивне став- } \\
\text { лення до життя }\end{array}$ & $38,53 \pm 17,73$ & $43,80 \pm 15,30$ & 1,23 & 0,22 \\
\hline Тонус: високий-низький & $51,93 \pm 5,86$ & $55,93 \pm 7,83$ & 2,24 & $\mathbf{0 , 0 2 9}$ \\
\hline Спокій - тривога & $52,26 \pm 9,14$ & $49,33 \pm 18,00$ & 0,79 & 0,43 \\
\hline $\begin{array}{l}\text { Стійкість - не стійкість } \\
\text { емоційного стану }\end{array}$ & $52,53 \pm 9,48$ & $50,40 \pm 16,04$ & 0,63 & 0,53 \\
\hline $\begin{array}{l}\text { Задоволеність - незадово- } \\
\text { леність життям в цілому }\end{array}$ & $58,13 \pm 9,09$ & $56,00 \pm 9,96$ & 0,87 & 0,39 \\
\hline $\begin{array}{l}\text { Позитивне-негативне уя- } \\
\text { влення про самого себе }\end{array}$ & $52,80 \pm 5,87$ & $54,47 \pm 8,78$ & 0,86 & 0,39 \\
\hline
\end{tabular}

$38,53 \pm 17,73$ та $43,80 \pm 15,30$; «Спокій - триво-

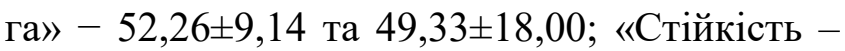

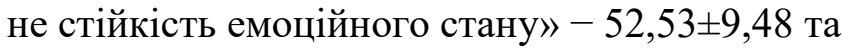
$50,40 \pm 16,04$; «Задоволеність - незадоволеність

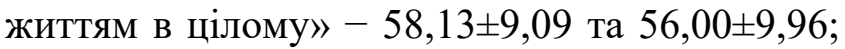
«Позитивне-негативне уявлення про самого себе» $-52,80 \pm 5,87$ та $54,47 \pm 8,78$.

За вищеозначеними шкалами математико-статистичний аналіз не виявив відмінностей у показниках домінуючих психічних станів між групами, сформованими за критерієм сімейного стану.

За шкалою «Тонус: високий-низький» у групі одружених комбатантів становить $51,93 \pm 5,86$, у групі не одружених комбатантів становить 55,93 $\pm 7,83$ ( $\mathrm{t}=2,24, \mathrm{p} \leq 0,029)$. Тобто одружені комбатанти мають більш стійку нервово систему, це пояснюється наявністю у них підтримки з боку сім’і. Неодружених комбатантів, характеризує більш висока акти- вність, більш виражене суб'єктивне відчуття внутрішньої зібраності, запасу сил та енергії.

Показники домінуючих психічних станів комбатантів у групах, сформованих за критерієм наявності дітей, надано в Таблиці 9.

Показники домінуючих психічних станів комбатантів у групах, представники якої мають або не мають дітей, відповідно склали: за шкалою «Активне-пасивне ставлення до

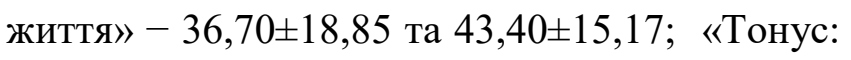

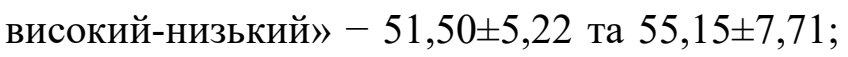

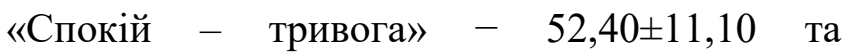

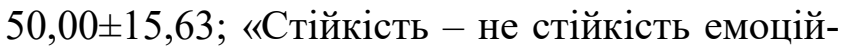

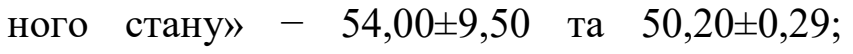
«Задоволеність - незадоволеність життям в

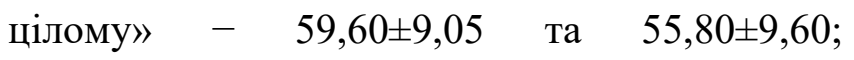
«Позитивне-негативне уявлення про самого

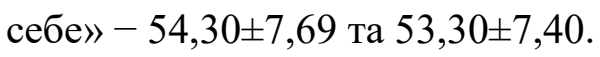

Математико-статистичний аналіз не виявив відмінностей у показниках доміную- 
Показники домінуючих психічних станів комбатантів за критерісм «Має/не має дітей»( $М \pm ð)$

\begin{tabular}{|l|l|l|l|l|}
\hline Показники & $\begin{array}{l}\text { I група N=40 } \\
\text { С діти }\end{array}$ & $\begin{array}{l}\text { II група N=80 } \\
\text { Не має дітей }\end{array}$ & T & P \\
\hline $\begin{array}{l}\text { Активне-пасивне ставлення } \\
\text { до життя }\end{array}$ & $36,70 \pm 18,85$ & $43,40 \pm 15,17$ & 1,48 & 0,14 \\
\hline Тонус: високий-низький & $51,50 \pm 5,22$ & $55,15 \pm 7,71$ & 1,90 & 0,06 \\
\hline Спокій - тривога & $52,40 \pm 11,10$ & $50,00 \pm 15,63$ & 0,61 & 0,54 \\
\hline $\begin{array}{l}\text { Стійкість- не стійкість емо- } \\
\text { ційного стану }\end{array}$ & $54,00 \pm 9,50$ & $50,20 \pm 0,29$ & 1,06 & 0,29 \\
\hline $\begin{array}{l}\text { Задоволеність - незадоволе- } \\
\text { ність життям в цілому }\end{array}$ & $59,60 \pm 9,05$ & $55,80 \pm 9,60$ & 1,47 & 0,14 \\
\hline $\begin{array}{l}\text { Позитивне-негативне уявлен- } \\
\text { ня про самого себе }\end{array}$ & $54,30 \pm 7,69$ & $53,30 \pm 7,40$ & 0,48 & 0,63 \\
\hline
\end{tabular}

чих психічних станів між групами, сформованими за критерієм наявності дітей.

Показники домінуючих психічних станів комбатантів у групах, сформованих за критерієм працевлаштування, надано в таблиці 10.

Не було встановлено вірогідних відмінностей у домінуючих психічних станах між групами комбатантів, які були працевлаштовані до війни, або були безробітні, за наступними шкалами, показники за якими склали відповідно:за шкалою «Тонус: високийнизький» - 54,29 $\pm 5,97$ та $53,47 \pm 8,55$; за шка-

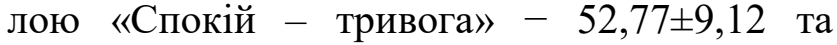
$48,23 \pm 18,87$; за шкалою «Стійкість - не стійкість емоційного стану» - 53,76 $\pm 8,02$ та

Таблиия 10.

Показники домінуючих психічних станів комбатантів за критерієм працевлаштування (M \pm ठ)

\begin{tabular}{|l|l|l|l|l|}
\hline Показники & $\begin{array}{l}\text { I група N=68 } \\
\text { працював }\end{array}$ & $\begin{array}{l}\text { II група N=52 } \\
\text { не працював }\end{array}$ & T & P \\
\hline Активне-пасивне ставлення до життя & $37,58 \pm 13,80$ & $45,84 \pm 19,01$ & 1,95 & $\mathbf{0 , 0 5}$ \\
\hline Тонус: високий-низький & $54,29 \pm 5,97$ & $53,47 \pm 8,55$ & 0,44 & 0,66 \\
\hline Спокій - тривога & $52,77 \pm 9,12$ & $48,23 \pm 18,87$ & 1,22 & 0,22 \\
\hline $\begin{array}{l}\text { Стійкість - не стійкість емоційного } \\
\text { стану }\end{array}$ & $53,76 \pm 8,02$ & $48,46 \pm 17,42$ & 1,57 & 0,12 \\
\hline $\begin{array}{l}\text { Задоволеність - незадоволеність жит- } \\
\text { тям в цілому }\end{array}$ & $57,41 \pm 9,22$ & $56,61 \pm 10,05$ & 0,31 & 0,75 \\
\hline $\begin{array}{l}\text { Позитивне-негативне уявлення про } \\
\text { самого себе }\end{array}$ & $51,70 \pm 5,89$ & $56,15 \pm 8,57$ & 2,37 & $\mathbf{0 , 0 2}$ \\
\hline
\end{tabular}




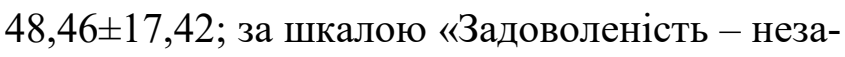
доволеність життям в цілому» $-57,41 \pm 9,22$ та $56,61 \pm 10,05$.

Вірогідно вищі показники за шкалою «Позитивне-негативне уявлення про самого себе» у другій групі $51,70 \pm 5,89$, ніж у першій $56,15 \pm 8,5756,15 \pm 8,57$, при $\mathrm{t}=2,37, \mathrm{p} \leq 0,02$. Тобто комбатанти, які не працювали, більше позитивно оцінюють себе, ніж ті, які працювали. Отже, комбатанти, що не були працевлаштовані до війни, менш критично оцінюють себе та більш схильні приймати себе з усіма своїми недоліками.

Ми вважаємо, що саме цим пояснюється оцінка ними свого стану як більш оптимістичного та активного, що відбивають вірогідно більш високі показники, отримані у групі військовослужбовців, які були безробітними, за шкалою «Активне-пасивне ставлення до життя» $(37,58 \pm 13,80)$ порівняно із групою, представники якої до війни були працевлаштовані $(56,15 \pm 8,57), \mathrm{t}=2,37, \mathrm{p} \leq 0,02$. Тобто комбатанти першої групи виявляють більшу пасивність до свого життя.

Висновки. Отже, вивчення чинників, що впливають на домінуючі психічні стани комбатантів АТО, дозволило встановити наступне:

- математико-статистичний аналіз не виявив значущих відмінностей у показниках домінуючих психічних станів між групами, представники яких перебували чи не перебували під обстрілами; між групами, сформова- ними за критерієм перебування на лікуванні у шпиталі; за критерієм «втрата близьких під час військової служби», за критерієм наявності дітей;

- у групі комбатантів, котрі спостерігали смерть під час військових операцій, за шкалою «Задоволеність - незадоволеність життям в цілому», показник був вірогідно вищим ніж у групі військовослужбовців, які не були свідками смерті. Тобто, комбатанти, які пережили смерть бойових друзів, близьких людей виявляють здатність більше цінувати життя в цілому, більше задоволені його ходом та можливостями самореалізації. Вони відчувають більшу готовність долати труднощі в реалізації власних здібностей, більшу здатність брати на себе відповідальність та бачать більше можливостей зробити власний вибір;

- одним з найвпливовіших чинників на домінуючі психічні стани військових виявився термін перебування у зоні воєнних дій. За шкалою «Активне-пасивне ставлення до життя» в групі комбатантів, що перебували у зоні бойових дій до 60 днів, показник виявився значно вищим, ніж в групі військовослужбовців, які перебували в зоні бойових дій більше двох місяців. Тобто зі збільшенням часу перебування в АТО формується більш пасивне ставлення представників другої групи до життєвої ситуації, значно зменшується їх віра в можливість успішного подолання перешкод, знижуються настрій та оптимізм. Крім того, дослідження за цим критерієм показало, що комба- 
танти, що перебували у зоні бойових дій до 60 днів, меш критично оцінюють себе та більш схильні приймати себе з усіма своїми недоліками;

- за мотиваційним критерієм «доброволець-мобілізований» виявлена значуща відмінність за шкалою «Спокій - тривога». Комбатанти АТО, які є добровольцями, більш спокійні та більш впевнені в своїх силах та можливостях;

- за політичним критерієм «брав/не брав участі у Революції гідності» виявлено значущу відмінність показників за шкалами «Тонус: високий-низький» та «Задоволення/ незадоволення життям». У комбатантів, що брали участь у Революції гідності більш висока активність, більш виражене суб'єктивне відчуття внутрішньої зібраності, запасу сил та енергії. Щодо комбатантів, котрі не брали участі у Революції гідності, то їм більш притаманна задоволеність життям в цілому, його ходом та самореалізацією;

- за сімейним станом - неодружені комбатанти більш активні, у них більш виражене суб'єктивне відчуття внутрішньої зібраності, запасу сил та енергії, ніж у одружених комбатантів;

- між групами комбатантів, які були працевлаштовані до війни, або були безробітними виявлено значущі відмінності за показниками шкал «активне-пасивне ставлення до життя» та «позитивне-негативне уявлення про себе». Учасники АТО, що не були працевлаш- товані до війни, менш критично оцінюють себе та більш схильні приймати себе з усіма своїми недоліками. Ті ж військовослужбовці, яким прийшлося залишити свою роботу або бізнес заради служби виявилися більш пригніченими, засмученими та пасивними.

Таким чином, емпіричне дослідження показало, що найбільше на домінуючі психічні стани військовослужбовців впливають термін перебування у зоні бойових дій та занепокоєння, пов'язані 3 працевлаштуванням до служби. Такі ж чинники як перебування під обстрілами; перебування на лікуванні у шпиталі; наявність дітей не показали значущого впливу на емоційний стан комбатантів. Отримані результати емпіричного дослідження знайшли своє використання в роботі центру корекційної та психодіагностичної діяльності Харківського національного університету внутрішніх справ у процесі планування заходів щодо психологічної допомоги комбатантам та підтримки психологічного здоров'я військовослужбовців.

\section{Перспективи подалыших досліджень.}

Перебування на війні відноситься до тієї екстремальної ситуації, яка накладає свій відбиток на все подальше життя людини. Майже у всіх учасників бойових дій неминуче тією чи іншою мірою спостерігаються зміни у фізичному і психічному стані. Тому перспективою будь-яких студій у даному напрямку має стати розробка ефективних програм психологічної підтримки людям, які перебували в екстрема- 
льних умовах військових дій.

\section{Перелік використаних джерел:}

1. Ігумнова О. Б. Напрями психокорекції негативних психічних станів студентів / О.Б. Ігумнова // Наукові записки Національного університету «Острозька академія». - 2014. - №. 30. - С. 64-68.

2. Куликов Л. В. Психические состояния. Хрестоматия. / Л.В. Куликов. - СПб.-Москва-Харьков-Минск. - 2000. $-506 \mathrm{c}$.

3. Axelrod S. R. Symptoms of Posttraumatic Stress Disorder and Borderline Personality Disorder in Veterans of Operation Desert Storm / S. R. Axelrod, C.A. Morgan III, S. M. South-wick // Am. J. Psychiatry. - 2005. - Vol. 162. P.270-275.

4. Brewin Ch. R. Meta-analysis of risk factors for posttraumatic stress disorder in trauma-exposed adults / Ch.R. Brewin, B. Andrews, J.D. Valentine // J. of Consulting and Clinical Psychology. - 2000. - № 68 (5). - P. 748-766.

5. Hughes H. J. Going to war can be good for you: deployment to war in Iraq is associated with improved mental health for UK personnel / H.J. Hughes, F.Cameron, R. Eldridge, M. Devon, N. Greenberg, S. Wessely // Br. J.Psychiatry. - 2005. - № 2. - P. 36-37.

6. Joseph $S$. Growth Following Adversity: Positive Psychological Perspectives on Posttraumatic Stress/ S. Joseph // Psychological Topics. - 2009. - . Vol.18. - № 2. - P.335344.

7. Kulka R. A. Assessment of posttraumatic stress disorder in the community: prospects and pitfalls from recent studies of Vietnam veterans / R.A. Kulka, W.E. Schleng-er, J.A. Fairbank [et al.] // Psychol. Assessment. - 1991. - № 3. P. 547-560.

8. Maddi S. R. Hardiness and Mental Health / S. R. Maddi, D. M. Khoshaba // Journal of Personality Assessment. 1994. - Vol. 63. - №2. - P. 265-274.

9. Prigerson K. G. Combat trauma: trauma with highest risk of delayed onset and unresolved posttraumatic stress disor- der symptoms, unemployment and abuse among men / K.G. Prigerson, P.K. Maciejewski, R.A. Rosenheck // J. Nerv. Ment. Dis. - 2001. - № 189. - P. 99-108.

10. Roca R. P. Posttraumatic adaptation and distress among adult burn survivors / R.P. Roca, R.J. Spence, A.M. Munster // Am J. Psychiatry. - 1992. - V. 149. - P. 1234-1238. 11. Shalev A. Y. Predictors of PTSD in injured survivors: a prospective study / A.Y. Shalev, T. Peri, L. Canetti, S. Schreiber // Am J. Psychiatry. - 1996. - V. 153. - P. 219225.

12. Tedeschi R. G. Posttraumatic Growth: conceptual foundations and empirical evidence / R.G. Tedeschi, L.G. Calhoun // Psychological Inquairy. - 2004. - Vol. 15. - No 1. - P. 1-18.

\section{References (Transliteration):}

1. Igumnova $O$. B. Napryami psihokorektsIYi negativnih psihIchnih stanIv studentIv / O.B. Igumnova // NaukovI zapiski NatsIonalnogo unIversitetu «Ostrozka akademIya». - 2014. - \#. 30. - S. 64.

2. Kulikov L. V. Psihicheskie sostoyaniya. Hrestomatiya. / L.V. Kulikov. - SPb.-Moskva-Harkov-Minsk. - 2000.$506 \mathrm{~s}$.

3. Axelrod S. R. Symptoms of Posttraumatic Stress Disorder and Borderline Personality Disorder in Veterans of Operation Desert Storm / S. R. Axelrod, C.A. Morgan III, S. M. South-wick // Am. J. Psychiatry. - 2005. - Vol. 162. P.270-275.

4. Brewin Ch. R. Meta-analysis of risk factors for posttraumatic stress disorder in trauma-exposed adults / Ch.R. Brewin, B. Andrews, J.D. Valentine // J. of Consulting and Clinical Psychology. - 2000. - № 68 (5). - P. 748-766.

5. Hughes H. J. Going to war can be good for you: deployment to war in Iraq is associated with improved mental health for UK personnel / H.J. Hughes, F.Cameron, R. Eldridge, M. Devon, N. Greenberg, S. Wessely // Br. J.Psychiatry. - 2005. - № 2. - P. 36-37.

6. Joseph S. Growth Following Adversity: Positive Psychological Perspectives on Posttraumatic Stress/ S. Joseph // 
Psychological Topics. - 2009. - . Vol.18. - № 2. - P.335344.

7. Kulka R. A. Assessment of posttraumatic stress disorder in the community: prospects and pitfalls from recent studies of Vietnam veterans / R.A. Kulka, W.E. Schleng-er, J.A. Fairbank [et al.] // Psychol. Assessment. - 1991. - № 3. P. 547-560.

8. Maddi S. R. Hardiness and Mental Health / S. R. Maddi, D. M. Khoshaba // Journal of Personality Assessment. 1994. - Vol. 63. - №2. - P. 265-274.

9. Prigerson $K$. G. Combat trauma: trauma with highest risk of delayed onset and unresolved posttraumatic stress disorder symptoms, unemployment and abuse among men / K.G. Prigerson, P.K. Maciejewski, R.A. Rosenheck // J. Nerv. Ment. Dis. - 2001. - № 189. - P. 99-108.

10. Roca R. P. Posttraumatic adaptation and distress among adult burn survivors / R.P. Roca, R.J. Spence, A.M. Munster // Am J. Psychiatry. - 1992. - V. 149. - P. 1234-1238.

11. Shalev A. Y. Predictors of PTSD in injured survivors: a prospective study / A.Y. Shalev, T. Peri, L. Canetti, S. Schreiber // Am J. Psychiatry. - 1996. - V. 153. - P. 219225 .

12. Tedeschi R. G. Posttraumatic Growth: conceptual foundations and empirical evidence / R.G. Tedeschi, L.G. Calhoun // Psychological Inquairy. - 2004. - Vol. 15. - No 1. - P. $1-18$.

\section{Ievdokimova Olena}

Doctor of Psychology, Professor, Head of the Department of Sociology and Psychology of Kharkiv National University of Internal Affairs, Kharkov, (Ukraine)

\section{DETERMINANTS OF DOMINANT MENTAL STATES OF ATO COMBATANTS}

\section{ABSTRACT}

In the paper, the influence of a number of factors on the specificity of the dominant mental states of combatants was investigated.

In the article the mental state is considered as an integral characteristic of a person's mental activity for a certain period of time, showing the peculiarity of the course of mental processes depending on reflected objects and phenomena of reality, on the previous state and personality properties.

The dominant mental state is considered as a condition that is characteristic not so much of a given particular moment, which depends on the characteristics of a particular situation, but much more in general for a certain period of a person's life. The dominant mental state is less conditioned by the actual, current situation, has an accurately delineated time frame, and is largely determined by socio-psychological personal factors. On the background of the dominant states, actual states are formed and exist.

Dominant states can be determined by many influences. The purpose of this work is to reveal the specifics of the dominant mental states of combatants, depending on such seemingly obvious, but, as it turned out, little studied factors like "was or was not the combatant under fire", "was/was not treated in hospital", "was / was not a witness of death", "volunteer / mobilized", "whether there were losses of friends during military service", depending on the period of staying in the war zone, on marital status, on the availability of children, on the availability of employment before

To determine the characteristics of the dominant mental states, the technique "Determination of dominant states" by 
L. Kulikov was used.

Mathematical and statistical analysis did not reveal significant differences in the indicators of dominant mental states between groups whose representatives were / were not under fire; between the groups formed according to the criterion of staying in the hospital; by the criterion of "loss of friends during military service", by the criterion of having children.

In the military group who observed death during military operations, on the scale "Satisfaction - dissatisfaction with life as a whole", the figure was significantly higher than in the group of servicemen who were not witnesses of death. That is, combatants who survived the death of fighting friends, close people, found the ability to value life more in general, more satisfied with its current and opportunities for selfrealization. An empirical study showed that of all the factors were studied, the greatest influence on the dominant mental states of servicemen has a "period of staying in the war zone" and anxiety connected with job in the pre-war period.

Key words: factors, dominant mental states, combatants.

\section{Евдокимова Елена Александровна}

Доктор психологических наук, профессор, заведующая кафедрой социологии и психологии Харьковского нациионального университета внутренних дел, г. Харьков (Украина)

\section{ДЕТЕРМИНАНТЫ ДОМИНИРУЮЩИХ ПСИХИЧЕСКИХ СОСТОЯНИЙ УЧАСТНИКОВ АТО}

Аннотация. В предлагаемой работе исследовано влияние ряда факторов на специфику доминирующих психических состояний участников боевых действий.

Психическое состояние рассмотрено в статье как целостную характеристику психической деятельности человека за определенный период времени, показывающую своеобразие протекания психических процессов в зависимости от отраженных предметов и явлений действительности, от предыдущего состояния и свойств личности.

Доминирующее психическое состояние рассмотрено как состояние, которое характерно не столько в данный конкретный момент, зависит от особенностей определенной ситуации, сколько вообще для определенного периода жизни человека. Доминирующее психическое состояние в меньшей степени обусловлено актуальной, текущей ситуацией, имеет точно очерченные временные рамки, и в большей степени определяется социальнопсихологическими личностными факторами. На фоне доминирующих состояний формируются и существуют актуальные состояния. 
Доминирующие состояния могут определяться многими влияниями. Цель данной работы - выявить специфику доминирующих психических состояний участников боевых действий в зависимости от таких, на первый взгляд, очевидных, но, как выяснилось, мало исследованных факторов как «был или не был исследуемый под обстрелами», «находился / не находился на лечении в госпитале», «был / не был свидетелем смерти», «доброволец/ мобилизованный», «были ли потери близких во время военной службы», в зависимости от срока пребывания в зоне боевых действий, от семейного положения, от наличия детей, от наличия трудоустройства до военных событий и тому подобное.

Для определения особенностей доминирующих психических состояний была использована методика «Определение доминирующих состояний» Л. В. Куликова.

Математико-статистический анализ не выявил значимых различий в показателях доминирующих психических состояний между группами, представители которых находились/ не находились под обстрелами; между группами, сформированными по критерию пребывания на лечении в госпитале; по критерию «потеря близких во время военной службы», по критерию наличия детей.

В группе военных, которые наблюдали смерть во время военных операций, по шкале «Удовлетворенность - неудовлетворенность жизнью в целом», показатель был достоверно выше, чем в группе военнослужащих, которые не были свидетелями смерти. То есть, комбатанты, пережившие смерть боевых друзей, близких людей, обнаружили способность больше ценить жизнь в целом, более довольны ее течением и возможностями самореализации. Эмпирическое исследование показало, что из всех исследованных факторов наибольшее влияние на доминирующие психические состояния военнослужащих имеют срок пребывания в зоне боевых действий и беспокойства, связанные с работой в довоенный период.

Ключевые слова: факторы, доминирующие психические состояния, комбатанты.
Дата отримання статті: 10.06.2018 Дата рекомендації до друку: 17.06.2018 Дата оприлюднення: 02.07.2018 